\title{
Ground Nesting of the Eastern Turtle Dove Streptopelia orientalis
}

\author{
Noritomo Kawaji*
}

Key words: Eastern Turtle Dove, Ground nesting, Western Hokkaido, Bamboo grass cover

The Eastern Turtle Dove Streptopelia orientalis breeds in the warmer eastern areas of the Palearctic region (O. S. J. 1974). It prefers forests or woody farmlands as breeding habitat, and makes a rough arboreal nest using fine twigs with little lining on a thin platform. However, I found a ground nest with two eggs in the experimental forest of the Hokkaido Research Center, Forestry and Forest Products Research Institute $\left(42^{\circ} 58^{\prime} \mathrm{N}\right.$, $141^{\circ} 23^{\prime}$ E, $100 \mathrm{~m}$ above sea level) near Sapporo city, western Hokkaido on May 29, 1989 (Fig. 1). The nest was made in 70-80 year old deciduous burned mature forest which is dominated by white birch (Betula platyphylla), Mongolian oak (Quercus mongolica) and Japanese linden (Tilia japonica). The nest was found under the dense undergrowth which mostly consists of a kind of the bamboo grass (Sasa kurilensis) (Fig. 2).

As with their arboreal nests, the Eastern Turtle Dove had used the fine twigs of white birch and Japanese linden to make the ground nest. The vegetation around the ground nest was as follows: The tree layer consisted mainly of white birch. The DBH (diameter at breast height) was $193 \pm 50.3 \mathrm{~mm}$ (mean \pm s. d.), the height was $16.6 \pm 1.89 \mathrm{~m}$, and the density was $3.82 / 100 \mathrm{~m}^{2}$. The shrub layer consisted of panicle hydrangea (Hydrangea panicudlata). The DBH of the shrub layer was $63.3 \pm 24.9 \mathrm{~mm}$, the height was $3.3 \pm 0.6$

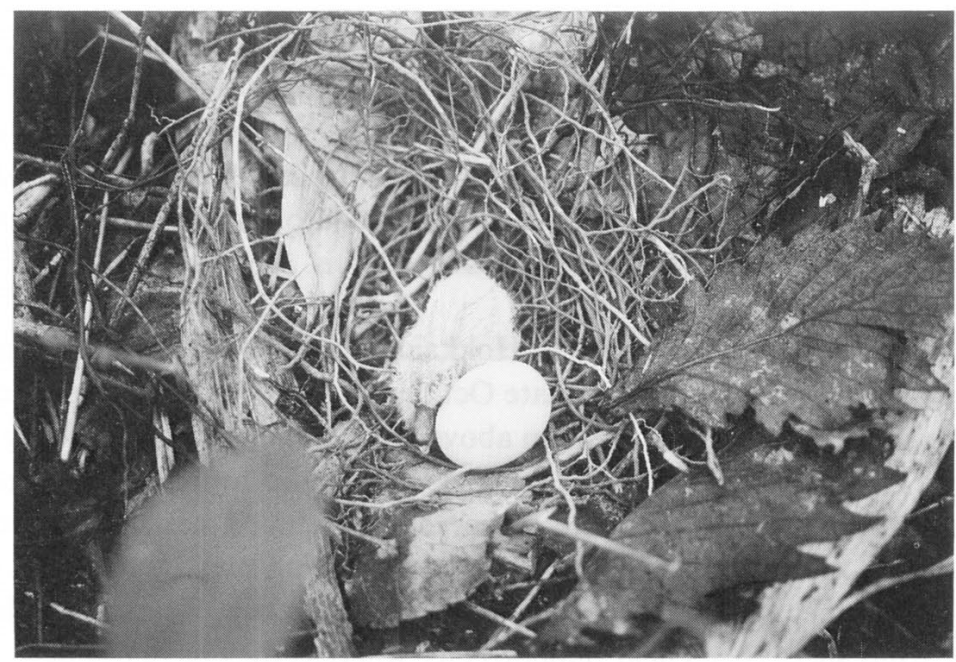

Fig. 1. An egg and a nestling on the ground nest of the Eastern Turtle Dove.

Received 7 March 1994, Revised 22 April 1994, Accepted 25 April 1994.

* Hokkaido Research Center, Forestry and Forest Products Research Institute, Hitsujigaoka-7, Toyohira, Sapporo, 062 Japan. 


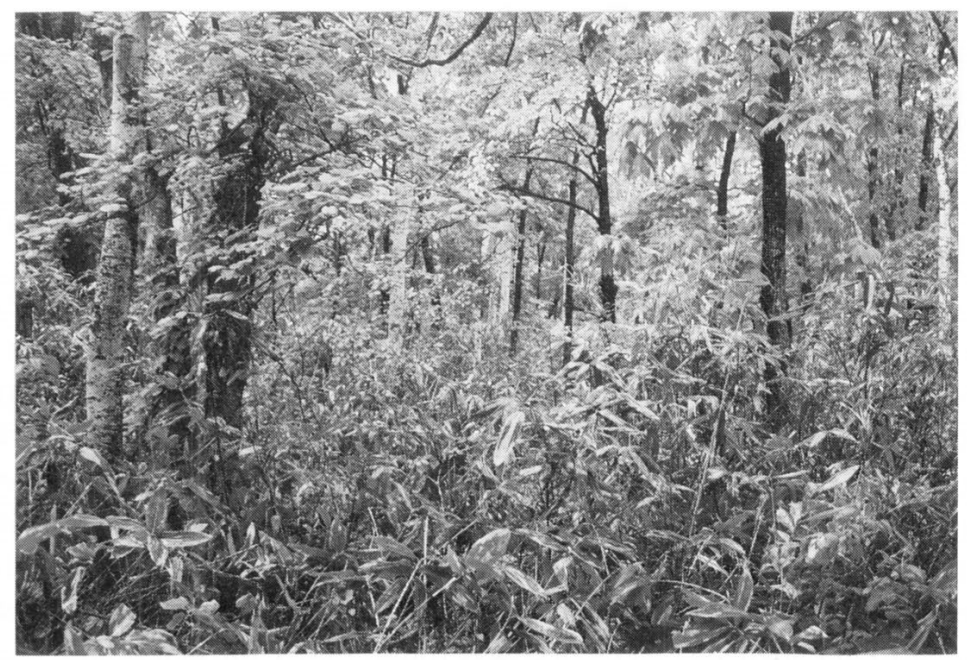

Fig. 2. The surrounding environment of the ground nest.

$\mathrm{m}$, and the density was $3.0 / 100 \mathrm{~m}^{2}$. The vegetation floor consisted of bamboo grasses (Fig. 2). The bamboo grasses height was $198.2 \pm 29.3 \mathrm{~cm}$, and the density $80 \mathrm{stems} / \mathrm{m}^{2}$. The vegetational condition around the ground nest site was not characteristic in the forest area because vegetational examination data which were obtained from 25 sites selected by random sampling within a 50 ha area including the nest site, showed no significant difference from the above-mentioned data.

One egg hatched on May 30, and the other on May 31. The former nestling fledged on June 13, and the latter on June 14. The nestling periods were the same as those of the arboreal nests in eastern Hokkaido (Murakami \& Fujimaki 1983).

Ground nesting of the Eastern Turtle Dove had been reported only on a small islet in the Ryukyu Islands, in the southern part of Japan (Kuroda 1972). Doves bred in a colony on the islet, and it has been suggested that few predators and sparce overstories make ground nesting appropriate because the small islet is removed from the main island (Kuroda 1972).

Most Eastern Turtle Doves arrive in Hokkaido from the south in late March or early April and stay until migrating south in late October. Most of the dove nests in the eastern part of Hokkaido were between 1 and $3 \mathrm{~m}$ above the ground, but their nesting success was very low (only 25\%) (Murakami \& Fujimaki 1983). I also found many arboreal nests in the experimental forest and frequently observed abandoned nests during the breeding season. However, more samples of dove's ground nesting may be detected especially in western Hokkaido, because some ground nests were already observed in the deciduous forest for the wind shelterbelts near Sapporo city whereas they have not been reported (S. Matsuoka \& H. Abe pers. comm.).

One of the probable reasons that doves select the ground as a nesting site in western Hokkaido is that there are few predators or low predation pressures on the ground. Artificial nest experiments showed lower nest failures on the ground than in the arboreal 
near the dove's ground nesting site (Kawaji 1994). The dove's nests usually become dirty during the nestling periods by the excretions of the young, which may attract nocturnal scent dependent predators. If more fledging successes from the ground nests of the dove were reported, it would suggest that such predators are scarce.

I would like to thank following people for their valuable information and useful comments about the ground nesting of the Eastern Turtle Dove; Drs. H. Abe, Y. Fujimaki, H. Higuchi, T. Hino, K. Ishigaki, S. Matsuoka, T. Nakamura and Messrs. H. Kawachi, I. Ogawa, K. Sonobe.

\section{References}

Kawaji, N. 1994. Lower predation rates on artificial ground nests than arboreal nests in western Hokkaido. Jpn. J. Ornithol. 43: 1-9.

Kuroda, N. 1972. Spring bird census in the Ryu Kyu Is. (1972). Misc. Rep. Yamashina Inst. Ornith. 6: 551568. (In Japanese with English summary.)

Murakami, J. \& Fujimaki, Y. 1983. Breeding biology of Rufous Turtle Dove Streptopelia orientalis in the Tokachi District, Hokkaido. Tori 31: 95-106. (In Japanese with English summary.)

Ornithological Society of Japan (O.S.J.) 1974. Check-list of Japanese birds. 5th revised ed. Gakken, Tokyo. 364 pp.

\section{キジバトの地上営巣}

キジバトは森林や農耕地に生息し，低木の茂み等に小枝を組み合わせて簡単な巣をつくる樹上営巣性鳥 類である.ところが，筆者は 1989 年 5 月 29 日に，札幌市郊外の森林総合研究所北海道支所の実験林内にあ るシラカンバ・ミズナラを主体とする山火再生天然広葉樹林において，抱卵中のキジバトの地上巣を発見

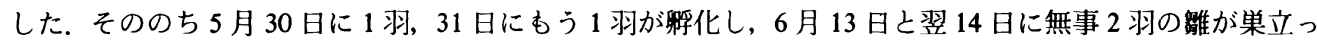
た. 地上巣付近における植生環境として，高木層にはシラカンバとシナノキ, 低木層にはノリウッギがある が, それほど多くなく, 林床植生として丈の高いチシマザサが比較的密生していた. 地上巣付近での植生条 件は，周辺のそれと特別変わったことはなかった。

キジバトの地上営巣については，これまでに琉球諸島の離島における集団営巣の例が知られている（黒 田 1972). その原因として, 天敵の希薄な離島という特殊な環境条件が挙げられているが, 今回のように, キジバトが北海道の内陸部です地上営巣することは, きわめて興味深いと考えられる.また, 通常育解中に 雊の排泄物が堆積するようなキジバトの巣は，おもに嗅覚に依存する捕食者を誘引する要因にもなると考 えられるが，今回巣立ちに成功したことは，この巣の周辺ではこれらの捕食者相が希薄であったことを示 唆するものである.

川路則友：農林水産省森林総合研究所北海道支所 $\overline{\mathbf{T}} 062$ 北海道札幌市豊平区羊ヶ $\mathrm{C} 7$ 番地 